\title{
Vegetation changes in boreo-nemoral forest stands depending on soil factors and past land-use during an 80- year period of no human impact
}

\begin{tabular}{|r|l|}
\hline Journal: & Canadian Journal of Forest Research \\
\hline Manuscript ID & cjfr-2015-0343.R2 \\
\hline Manuscript Type: & Article \\
\hline Date Submitted by the Author: & 10 -Dec-2015 \\
\hline & $\begin{array}{l}\text { Complete List of Authors: } \\
\text { Karth Sciences } \\
\text { Kolava, Arta; University of Latvia, Faculty of Geography and Earth Sciences } \\
\text { Nikodemus, Olǵerts; University of Latvia, Faculty of Geography and Earth } \\
\text { Sciences } \\
\text { Grods, John; Makonis Consulting Ltd., } \\
\text { Elferts, Didzis; University of Latvia, Faculty of Biology }\end{array}$ \\
\hline Keyword: & $\begin{array}{l}\text { conservation, management, succession, understory vegetation, } \\
\text { regeneration }\end{array}$ \\
\hline \multicolumn{2}{|l}{} \\
\hline
\end{tabular}

\section{SCHOLARONE}

Manuscripts 
1 Vegetation changes in boreo-nemoral forest stands depending on soil factors and past

2 land-use during an 80-year period of no human impact

3

4 Ilze Kokarēviča, Guntis Brūmelis ${ }^{1}$, Raimonds Kasparinskis, Arta Rolava, Oḷǵerts

$5 \quad$ Nikodemus, John Grods and Didzis Elferts

6

7 Ilze Kokarēviča, Guntis Brūmelis, and Didzis Elferts. Faculty of Biology, University of

8 Latvia, Jelgavas iela 1, Rīga, LV1004, Latvia, (email: ilze.kokarevica@gmail.com,

9 guntis.brumelis@1u.lv, didzis.elferts@lu.lv)

10 Raimonds Kasparinskis, Arta Rolava and Oḷgerts Nikodemus. Faculty of Geography and

11 Earth Sciences, University of Latvia, Jelgavas iela 1, Rīga, LV1004, Latvia (email:

12 raimonds.kasparinskis@lu.lv, arta.rolava@lu.lv, olgerts.nikodemus@lu.lv)

13 John Grods. Makonis Consulting Ltd., 955 Westbrook Drive, West Kelowna, BC, V1Z

14 1R5, Canada (email: john@makonis.com).

15

16

17

$18{ }^{1}$ Corresponding author: Guntis Brūmelis. Faculty of Biology, University of Latvia, 19 Jelgavas iela 1, Rīga, Latvia, LV1004 (tel: +371 29482107, email: guntis.brumelis@lu.lv) 


\section{Abstract}

22 Information on the long-term changes in plant communities that occur without human

23 interference is limited, due to insufficient studies where vegetation can be resurveyed. In

24 1912, a strict nature protection reserve, with non-intervention management, was

25 established on Moricsala Island in Latvia, located in the boreo-nemoral forest zone. Prior

26 to establishment of the nature reserve, part of the island area was used for agriculture. The

27 island is now covered almost entirely by forest dominated by Quercus robur and Tilia

28 cordata on sandy soils. Resurvey was conducted in 2011 in seventeen plots in which tree

29 layers and the understory vegetation had been described in 1930. The plots were

30 classified into two groups based on tree species composition in 1930, to determine

31 changes in species composition. Differences in understory and tree canopy composition

32 between these groups persisted over the period between the studies, in relation to soil

33 factors and past stand history. Considerable turnover of species occurred, with decrease of

34 species typical of open habitats and replacement by species typical of nemoral (temperate

35 deciduous) forest plant communities. In the past, Quercus robur had likely established in

36 open habitats created by agricultural land-use or past fire, but is presently not

37 regenerating in the understorey.

40 Keywords: management, understory vegetation, conservation, succession, regeneration. 
41

42

43

44

\section{Introduction}

2

$$
\text { In densely populated regions of Europe, the legacies of land-use have profoundly }
$$

affected forest fragmentation and biodiversity (Hermy and Verheyen 2007). In regions where much of the existing forest area has been previously used for agriculture, differences between plant communities in secondary forests and woodland that has been forested for a long time (ancient forest) can persist for a long time (Baeten et al. 2010) due to seed dispersal constraints and altered soils (Hermy et al. 1999). Soil properties of parent material and relief form a template governing development of understory vegetation, but canopy type is an important soil forming factor (Jenny 1994). Coniferous and deciduous tree stands differ in humus quality, humus accumulation rate, decomposition of litter and formation of a forest floor layer ( (Vesterdal and RaulundRasmussen 1998; Vesterdal 1999; Vesterdal et al. 2008;). Picea abies litter accumulation promotes soil podzolization, which can be reversed under deciduous trees (Bonifacio et al. 2008). Therefore, changes in forest management that affect tree composition cause changes in understory plant communities not only directly by altering light regimes, but also indirectly via soil characteristics (Van Calster et al 2007). Thus, knowledge of the changes in understory vegetation in relation to soil formation processes, tree canopy composition and past land-use is required for development of biodiversity conservation strategies.

Few areas exist where natural plant successions (tree canopy and understory vegetation) in woodland undisturbed by man can be studied. Most old-growth "noble broadleaved" forest of the nemoral (temperate deciduous) zone has been converted to agricultural land-use in Europe, and reference natural woodland occurs only as small 
65

66

67

remnants in reserves (Peterken 1996). The Bialowieza reserve in Poland is one example of natural nemoral woodland that has been minimally undisturbed by humans, but even there the effects of past management in the late 1800 s-1900s can still be observed, i.e., facilitation of expansion of P. abies (Falinski 1988). Also, abundant Quercus robur regeneration in the past in the reserve is considered to be due to past human land use and game management (Bobiec 2012). Paleoecological data suggests that the structure of a historical temperate forest shared some of the mosaic attributes of traditional wood pasture, such as canopy gaps of various size (Bradshaw and Hannon 2004). Wooded meadow landscape has been a common feature in the boreo-nemoral transition forest zone of Northern Europe for centuries. However, much of this area has overgrown to forest, which raises the dilemma of whether restoration of traditional land-use by cutting encroaching trees around the remaining ancient trees of the past agricultural landscape is necessary (Palo et al. 2013). Among the typical "noble broadleaved" tree species (Quercus robur, Fraxinus excelsior, Tilia cordata, Acer platanoides, Ulmus glabra and Ulmus laevis and Acer sp.), Q. robur, which has a special value for cultural heritage and biological diversity in wooded meadow, is known for lack of ability to regenerate in densely shaded stands (Brūmelis et al. 2011, Palo et al. 2013). Therefore, natural forest development in the long-term can lead to a loss of the biological value associated with the previous land-use. However, Q. robur can successfully outgrow pioneer tree species in large canopy gaps created by windthrow in Picea abies woodland (Götmark and Kiffer 2014).

Identification of the factors governing changes in tree canopy composition and the understory vegetation can be attained by resurvey of territories that have been studied earlier (Kirby et al. 2005). These types of long-term studies can provide a wealth of 
89 information on natural tree stand development. A detailed ecological study was conducted 90 in 1928-1930 (Grošinskis 1932) on the plant communities in plots located in various

91 forest types in the Moricsala (Island) Nature Reserve in Latvia. The study included data

92 on herbaceous and woody plants in the understory, forest mensuration data and soil 93 profile descriptions. Since 1912, the reserve has had strict restrictions on access, and 94 hence no human impact for a period of over 100 years. Prior to establishment of the 95 reserve in 1912, part of the island was used for hay collection and represented a wooded 96 meadow landscape with various nemoral forest types dominated by $Q$. robur and $T$.

97 cordata, and also stands with Picea abies, Pinus sylvestris, Betula pendula, B. pubescens 98 and Populus tremula. Resurvey of the forest stands studied in 1928-1930 was conducted 99 to determine if changes in understory vegetation could be predicted by past stand history and tree species composition, in relation to soil characteristics. It was hypothesized that 1.

101 regeneration of $Q$. robur was not occurring, but that other nemoral species had increased

102 dominance in the canopy, 2. development of plant communities typical of noble broad-

103 leaved woodland would not occur under a P. abies tree canopy, due to unsuitable soil

104 conditions, and 3. loss of species typical of open habitats had occurred in plots during the 105 period between studies.

106 2. Materials and Methods

107 2.1. Site description

108 Moricsala Island (Fig. 1) is located in Lake Usmas (total area $34.7 \mathrm{~km}^{2}$ ), in Kursas 109 lowland of the Western part of Latvia. The size of Moricsala Island is 82.3 ha (length $1101700 \mathrm{~m}$; width in narrowest part 200m). It is part of the Moricsala Nature Reserve. The 111 reserve was founded in 1912 on the initiative of Karl Reinhold Kupffer with the support 112 of the Naturalists' Society of Riga (Kupffer 1931). Since establishment of the reserve, 
113 the management policy has been complete non-intervention, with visitation allowed only

114 by permit for specific reasons, such as research. Before creation of the reserve, about $30 \%$

115 of the island was used for harvest of hay and grazing in summer, and wood was removed

116 for firewood and building (Kupffer 1931). However, in view of the human footprint

117 already at that time, Moricsala was considered to be the best relict of oak-lime forest in

118 the eastern Baltic region. The only hay meadow today (1.1 ha) is around the previous

119 ranger's house on the north-western portion of the island.

120 Latvia is located in the boreo-nemoral zone. The climate of Western Latvia is

121 characterized as mild coastal with mean annual temperature is $5.5-5.8^{\circ} \mathrm{C}$ and the annual

122 precipitation is $700-800 \mathrm{~mm}$ (data from the Latvian Environment, Geology and

123 Meteorology Centre). The nature protection values of the island are associated with

124 natural mixed nemoral forest with oak $Q$. robur and lime $T$. cordata tree, as well as mixed

125 coniferous forest with spruce $P$. abies and pine $P$. sylvestris (Brūmelis et al. 2011). Areas

126 of lower depression are covered by black alder Alnus glutinosa woods.

127 2.2. Location of plots

128 A dissertation was defended in 1932 by V. Grošinskis (1932) on forest types on

129 Moricsala Island. In 1928-1930, vegetation and tree structure and composition were

130 described in plots, the locations of which were mapped and noted in the dissertation. The

131 historical maps were rectified to produce a digital map with coordinates of the plots using

132 Geographic Information System ArcGIS 10.0 with Spatial Analyst 10.0. A full

133 description of the maps used and methods for rectification are given as supplementary

134 material. The Pearson's correlation coefficient between matrices of inter-distances of

135 control points on the historical and new images was $0.999(\mathrm{p}<0.001$, Mantel test), which

136 confirmed validity of the used method. 
137 Geographical coordinates obtained from the produced digital map base were used to

138 locate the historical plots in the field during 2010-2012 field trips, after receiving

139 approval by the Latvian Nature Conservation Agency. Historical field descriptions by V.

140 Grošinskis of plot location could be used to verify correct locations in the field. For

141 several plots, the chosen locations by coordinates exactly matched the earlier descriptions

142 in the dissertation. For example, locating the plots by coordinates, two plots in small wet

143 Alnus glutinosa stands (data from these plots not used in the present study) were

144 precisely located in the middle of depressions, with plot sides extending almost to the

145 edges of the wet area. Two plots in a previously small burnt area had visible subsurface

146 charcoal. Also, sides of other plots that bordered on topographical slopes matched the

147 earlier descriptions. Thus, we are confident that the established plots were located in at

148 least the same forest stands, and that they at least partly spatially overlapped with the

149 historical plots.

150

\subsection{Field data collection}

152 The earlier methods for description of tree canopy structure and composition, and

153 woody and herbaceous understory vegetation, were used in a repeated survey of the plots

154 in July 2010-2012 (mostly July 2011). We restricted the study to 17 plots located on

155 similar dry sandy soil parent material. Three wet plots on hydromorphic soils were

156 excluded. Of the 17 plots, 15 had size $50 * 50 \mathrm{~m}$ and the other two were smaller with size

$15750 \mathrm{~m} * 20 \mathrm{~m}$. All trees with diameter at breast height $(\mathrm{DBH})>10 \mathrm{~cm}$ was measured in each

158 plot. In the earlier study, also age of selected overstory trees was estimated from cores

159 obtained using a Pressler increment borer. Tree saplings and seedlings (all stems $<10 \mathrm{~cm}$

$160 \mathrm{DBH})$ and tall shrubs were counted in the previous study in four to ten $4 * 4 \mathrm{~m}$ subplots. 
161 However, in the dissertation (Grošinskis 1932), the form of presenting sapling densities

162 varied: 1) counts of saplings and shrubs in the plots and as densities ha ${ }^{-1}, 2$ ) only as

163 densities $\mathrm{ha}^{-1}, 3$ ) only as qualitative descriptors (few, many, etc) and 4) combinations of

164 the above qualitative and quantitative approaches. For plots where only qualitative

165 descriptors were used, the number of saplings ha ${ }^{-1}$ could be estimated by qualitative

166 values based on information from plots where both qualitative and quantitative values

167 were given. The following conversion factors (number of saplings per ha ${ }^{-1}$ ) were used to

168 replace qualitative values: very sparse $-270 \mathrm{ha}^{-1}$, sparse $-1175 \mathrm{ha}^{-1}$, medium $-3890 \mathrm{ha}^{-1}$,

169 medium to dense $-4250 \mathrm{ha}^{-1}$, good $-8030 \mathrm{ha}^{-1}$, and very good $-16600 \mathrm{ha}^{-1}$. In the

170 resurvey, ten $4 * 4 \mathrm{~m}$ subplots for counting samplings were used in all plots, randomly

171 selected by throwing a stick (earlier method for selection not described).

172 In the previous study, the understorey herbaceous plant communities were described

173 in ten $1 * 1 \mathrm{~m}$ subplots in the larger plots. Complete lists of species in the plots were

174 recorded and frequency of occurrence in the subplots was estimated. We repeated this

175 method. Cover of each species was also estimated in both surveys, but it was considered

176 that cover estimation was not repeatable accurately and was not used for analysis.

177 In the present study, in consideration of minimizing effect on the habitat, soil profiles

178 were unearthed beside vegetation plots in the closest location without fallen trees and

179 dense shrubs. Soil profiles were described according to the FAO (Food and Agriculture

180 Organization of the United Nations) WRB (World Reference Base for Soil Resources)

181 soil classification system (IUSS Working Group WRB 2014). The soil morphology

182 descriptions and symbols of soil horizons are given according to the Guidelines for Soil

183 Description (FAO 2006). Soil samples in 3 replicates were taken as grab samples from the

184 litter O horizon and the surface mineral topsoil Ah horizon (identified by accumulation of 
185 organic matter). Depth to which samples were taken depended on the depth of the

186 horizon. The samples were placed in plastic bags and transported to the laboratory, where

187 they were immediately processed. In the previous study, the methods used for description

188 of soil morphology vastly differed. However, qualitative descriptions of horizons allowed

189 to cross-reference $\mathrm{O}$ and Ah horizons, and as depths of these horizons were measured in

190 both studies, we include this data in the analysis.

\section{$191 \quad$ 2.4. Soil analysis}

192 Laboratory analyses were conducted according to standard methods used in ICP

193 (International Co-operative Programme) Forest monitoring methods (Cools and de Vos

$1942010)$ to determine soil texture, soil $\mathrm{pH}_{\mathrm{KCl}}$ value, total nitrogen (\%), total organic carbon

$195(\%)$ and total nitrogen concentrations and total organic carbon/nitrogen concentration 196 ratio of the $\mathrm{O}$ and $\mathrm{Ah}$ horizons.

197 The mineral soil samples were dried at air temperature and sieved using a 2-mm mesh. Material from the litter layer was sieved using a 4-mm mesh. Soil fractions were determined by pipetting method (van Reeuwijk 1995) after treatment with $0.1 \mathrm{M} \mathrm{NaOH}$ to break down aggregates. The soil fractions were defined by particle size according to the USDA soil texture classification (Cools and de Vos 2010): sand -0.063 to $2.0 \mathrm{~mm}$, silt -0.002 to 0.063 , clay $-<0.002 \mathrm{~mm}$. The percentages of sand, silt and clay were 203 calculated from fine earth $(<2 \mathrm{~mm}$ fraction). Soil textural classes were determined according to the Guidelines for Soil Description (FAO 2006).

205 Soil $\mathrm{pH}$ was determined with a glass electrode in $1 \mathrm{M} \mathrm{KCl}$ solution $(10 \mathrm{~g}$ soil and 50 $206 \mathrm{ml}$ solution in 3 laboratory replicates). Total nitrogen concentration (\%) was determined 207 using a CHNS-O Elemental Analyzer "Eurovector" EA3000 Series and total organic 208 carbon concentration (\%) was determined using a total organic carbon analyzer 
"Shimadzu TOC-Vcsn" and "Solid Sample Module SSM - 5000 A", where soil samples were heated at $900^{\circ} \mathrm{C}$ (ISO 10694 1995; ISO 13878 1998; Cools and De Vos 2010).

211 Analysis of soil samples was conducted using 3 replicates.

\section{$214 \quad$ 2.5. Data analysis}

215 In addition to a vegetation matrix of plant frequencies of occurrence in subplots, a 216 matrix consisting of ecological characteristics of plots was produced with the following 217 variables: weighted mean Ellenberg values of plants (weighted by frequency of 218 occurrence) for $\mathrm{pH}, \mathrm{N}$ and light, obtained from Ellenberg et al. (1991), and relative 219 frequencies of plants in plots by Raunkiaer life form, C-S-R plant strategies and dispersal 220 type, obtained mostly from the Biolflor (see supplementary material in Kühn et al. 2004) and Ecological Flora databases (Fitter and Peat, 1994). Barochorous species were combined together with autochorous species. In addition, species were grouped by their characteristic habitat: forest, grassland, other open habitats (forest edges, clearings, clearcuts), and both forest and grassland. Other matrices produced consisted of data on basal area of trees by species and counts of saplings by species calculated as densities in $4 * 4 \mathrm{~m}$ subplots.

Classification of plots into groups was made using cluster analysis (Ward's method with correlation distance measure) using PCORD version 5. For comparison of values between these groups, a permutation test was chosen for herb relative frequencies, ecological 230 characteristics, species richness, soil variables, tree basal area and sampling densities, 231 since most of these variables did not correspond to a normal distribution and tests showed 232 heteroscedasticity of variance. To compare changes in variables between studies, a paired 
233 permutation test (herb relative frequencies, ecological traits, species richness, $\mathrm{O}$ and $\mathrm{Ah}$ 234 horizon depths, tree basal area and sampling densities) was used. Significant differences 235 in the proportion of plots occupied by herb and sapling species between years and plot 236 groups were determined using a test for equality of proportions. All tests were performed 237 using program R 3.1.3 (R Core Team 2015), with permutation tests as implemented in 238 library coin of this program (Hothorn et al. 2008). A non-metric multidimensional scaling 239 ordination (NMS) of the vegetation matrix was performed using PCORD version 5

240 (McCune and Grace 2002).

\section{Results}

\subsection{Tree species composition}

Cluster analysis of plots based on basal areas of tree species in 1930 classified the plots into a larger group of 8 plots, all dominated by $Q$. robur, and three small groups of

2, 3 and 4 plots dominated by different combinations of Picea abies, Pinus sylvestris and pioneer species (Betula sp. and Populus tremula). The estimated age of the canopy trees in the $Q$. robur stands in 1930 was 90-100 years (Table 1). Five of the eight plots (plots

250 The three small groups included plots that had regenerated after use as wooded pasture 251 (plots 11 and 12), after a fire in about 1900 (plots 8 and 20), after a bark beetle outbreak 252 (plot 8) or after selective cutting (plots 9 and 6). Thus, it was considered that the three 253 groups represented an early to mid secondary succession stage after a major disturbance 254 or land-use change. Field descriptions of two of the stands (one dominated by P. tremula 255 (plot 21) and the other by P. abies (plot 18) did not include notes on the past disturbance, 256 but in the cluster analysis were included in two of the three secondary succession groups. 
257 In further analysis, the three small groups were combined to form a larger group

258 containing stands that contained variable composition of conifers and pioneer tree

259 species, and which mostly represented an early to mid successional stage after a major

260 disturbance or land-use change (further called the conifer/pioneer-dominated group).

261 Comparing the two defined groups, in 1930, the Quercus-dominated plots had

262 significantly larger basal area of $Q$. robur, T. cordata and A. platanoides (Table 2). In

263 2011, comparing the two groups, the conifer/pioneer-dominated group had significantly

264 larger basal area of P. sylvestris, P. tremula and Betula sp. (Table 2) and higher shrub

265 layer densities of $Q$. robur and P. abies. Between the two years of study, basal area of $A$.

266 platanoides and Betula sp. significantly decreased in the conifer/pioneer-dominated group

267 (Table 2). In the conifer/pioneer species group, basal area of Q. robur, T. cordata and A.

268 platanoides increased by 2-6 times, but non-significantly (Table 2), while density of $Q$.

269 robur in the understory had significantly decreased (Table 3).

270 Comparing the two defined groups, in 1930 the conifer/pioneer-dominated group had

271 higher occurrence of P. tremula in the overstory (Table 3). Between the two years of

272 study, occurrence in plots of P. tremula and Betula sp. significantly decreased in the

273 Quercus-dominated plots (Table 2). In the conifer/pioneer species group, occurrence of

274 Q. robur in the understory had significantly decreased between years (Table 3); in both

275 groups, Q. robur was no longer found in the understory in 2011.

276

\section{$277 \quad$ 3.2. Soil characteristics}

278 In 1930, the thickness of the O horizon did not significantly differ between the two 279 groups of plots. However, in the period since 1930, the thickness of the O horizon had 280 significantly increased in the conifer/pioneer tree species plots. Based on data from soil 
281 pits studied in 2011, soil in the plots had sandy soil texture in the topsoil with weakly 282 (Arenosols and Cambisols) to well formed soil horizons (Podzols). Depth to silty loam 283 parent material mostly occurred in the soil profiles at a depth $>100 \mathrm{~cm}$ (Table 4), but was 284 less than $50 \mathrm{~cm}$ in two plots. Depth to free carbonates $\left(\mathrm{CaCO}_{3}\right)$ was less than $1 \mathrm{~m}$ in three 285 plots. Charcoal was found in the $\mathrm{O}, \mathrm{Ah}, \mathrm{Bs}$ or Bt horizon in 13 of the 17 plots (Table 1). 286 While the soil texture of the topsoil in all plots of the two tree composition groups was 287 sand, several soil variables significantly differed between the groups. The $\mathrm{pH}$ of the $\mathrm{O}$ 288 horizon and N concentration of the Ah horizon were significantly higher in the Quercus289 dominated plots (Table 4). Thickness of the $\mathrm{O}$ horizon, $\mathrm{C}$ concentration and the $\mathrm{C} / \mathrm{N}$ ratio 290 in the O horizon, were higher in the conifer/pioneer-dominated group.

\subsection{Ecological characteristics}

In comparison with the conifer/pioneer species group, in 1930 the Quercus-dominated group had greater relative frequency of chamaephytes (plants with resting buds close to soil surface), species with autochorous (self) seed dispersal and species with an intermediate competitive stress-tolerant ruderal CSR strategy (Table 5). In 2011, chamaephytes remained relatively more frequent in this group. In addition, the weighted mean $\mathrm{pH}$ and $\mathrm{N}$ Ellenberg values were higher in this group, and ant-dispersed myrmecochorous (ant-dispersed) species and those characteristic of both forest and grassland were relatively more frequent. Between the two times of study, relative frequency of plants with a competitive-stress tolerant CS strategy and autochorous seed dispersal mechanism had decreased, while species characteristic of moist habitats had higher frequency (Table 6).

Compared with the Q. robur-dominated group, in 1930 the conifer/pioneer tree species group of plots had significantly greater relative frequency of hemiphanerophytes 
305 (dwarf shrubs), therophytes (annuals), plants with a CR strategy and wind-dispersed seed, 306 and plants characteristic of open habitats (Table 5). In 2011, higher relative frequency of

307 hemiphanerophytes (buds at or near the soil surface) and species of open habitats had

308 remained higher in the conifer/pioneer species group, but there was also significantly

309 higher relative frequency of plants with a stress-tolerant S strategy and plants

310 characteristic of forest habitats. Between the two years of study, a greater number of

311 significant differences in ecological characteristics of the plant communities occurred in

312 the conifer/pioneer species group than in the Quercus-dominated group (Table 6). The

313 relative frequency of geophytes (with an underground storage organ), and species with

314 both geophyte and hemicryptophyte (buds at or near the soil surface) life forms, and

315 species with a S strategy, zoochorous (animal dispersed) seed dispersal mechanism had

316 significantly increased. These changes occurred alongside decreased relative frequency

317 of therophytes, hemiphaneropytes, species with a competitive ruderal CR strategy and

318 species characteristic of both forest and grassland.

$319 \quad 3.4$. Species composition

320 Mean species richness did not significantly differ between the two stand groups nor

321 between years of study: 23.5 and 23 species in the conifer/pioneer trees species group and

$322 \quad 23.8$ and 20.1 in the Quercus-dominated group. Of the species that are protected today

323 (there were no protected species lists in the earlier period), only one, Dentaria bulbifera

324 was recorded in plots in 1928-1930, but in addition to this species, Circaea lutetiana and

325 Festuca altissima were recorded in the recent survey.

326 The conifer/pioneer tree species group was characterized by plant species typical of

327 coniferous forest, like Vaccinium species and Trientalis europaea, along with species

328 characteristic of open habitats, such as the graminoids Festuca ovina and Deschampsia 
329 flexuosa, the herb Melampyrum nemorosum and fern Pteridium aquilinum (Table 7).

330 Compared to the plant communities of the conifer/pioneer tree species group, the

331 Quercus-dominated group of plots had higher relative frequency of woodland herbs like 332 Aegopdium podagraria and Paris quadrifolia (Table 7).

333 Over the 80-year period between the two studies, species characteristic of open

334 habitats and forest/grassland, like Fragaria vesca, V. chamaedrys and M. nemorosum in 335 the conifer/pioneer tree species and Athyrium felix-femina in the Quercus-dominated 336 group had decreased in relative frequency. The other plant species showing significant 337 positive or negative change were forest species. Of those, significant increase in relative 338 frequency occurred for Circaea lutetiana in both plot groups, Dryopteris carthusiana in 339 the Quercus-dominated group, and Galium odoratum, Veronica officinalis, and Oxalis 340 acetosella in the conifer/pioneer species group (Table 8). In plots of the Quercus-

341 dominated group, species characteristic of perhaps more open forest habitat, like Geum 342 urbanum, and also some species of closed deciduous forest habitat, like Polygonatum 343 multiflorum, had become less frequent. Vaccinium species became less frequent in the 344 conifer/pioneer species group.

345 The NMS ordination of vegetation data (Figure 2) showed a fairly good separation of 346 the two tree species groups. The two post-fire groups are located at the bottom of the 347 ordination. However, two plots of the conifer/pioneer species group occurred within the 348 cluster of Quercus-dominated plots. The plots at the bottom of the ordination show a 349 unidirectional change in species composition to the right side, while the change in the 350 Quercus-dominated group is not consistent. The vegetation gradients in the ordination can 351 be explained by the same significant factors (Figure 2B) obtained in the above explicit 352 analysis, for example, greater occurrence of species of open habitats in the 
353 conifer/pioneer species group and species with higher Ellenberg values for $\mathrm{pH}$ and $\mathrm{N}$ in

354 the Quercus-dominated plots. Between the periods, depth of the O horizon and

355 occurrence of stress-tolerant species increased, shown by vectors directed to the right side

356 of the ordination (Fig. 2).

357

358 4. Discussion

359 The present vegetation of the Moriscala Nature Reserve has developed as a result of

360 past land-use and natural and human-caused disturbance interacting with soil formation

361 processes. An intrinsic problem in the study was low number of plots imposed by the plot

362 design in the early part of last century, in relation to the variability in soils and canopy

363 composition and the vast number of characteristics examined. We divided the stands into

364 two groups. The conifer/pioneer tree species group was not homogenous and included

365 various combinations of tree species and different past history. It was not subdivided

366 further as this would not allow statistical comparison. However, it did differ statistically

367 from the Quercus-dominated group in canopy, soil and vegetation characteristics, which

368 suggests that this grouping was valid. Also, the NMS ordination indicated fairly good

369 separation of the two groups in vegetation composition. The large number of

370 characteristics examined increased the probability of a chance significant difference

371 between the plot groups, and certainly correcting for chance in statistical analysis led to

372 fewer significant differences. However, groups of plant ecological characteristics and soil

373 variables with significant differences without correction for chance effect did suggest the

374 same overall features that are known to be characteristic of particular communities,

375 indicating their validity. Nevertheless, interpretation requires caution.

376 4.1. Canopy composition in relation to soil factors 
All studied forest stands had similar soil texture, but stands characterized by various

378

380

381

382

384

385

386

387

combinations of dominance by conifer $(P$. sylvestris and $P$. abies $)$ and pioneer tree $(P$.

tremula and Betula sp.) species had a deeper, less decomposed (higher $\mathrm{C} / \mathrm{N}$ ratio) and more acidic $\mathrm{O}$ horizon. The conifer/pioneer species group was variable in canopy structure and composition, having developed after different pre-1930 history of fire, forest-pasture use, cutting and natural disturbance. The past disturbance in the stands can explain the greater dominance of the pioneer tree species. The lower $\mathrm{pH}$ can be explained by the strong acidifying effect of coniferous litter (Hagen-Thorn et al. 2004), which accelerates podzolization and leaching of soluble organo-mineral complexes and carbon to deeper soil layers (Lundström et al. 2000). Litter from coniferous forests decomposes slower than litter from deciduous forests and accumulates in the forest litter layer (Berg 2000). The effect of coniferous trees on soils of deciduous forests has been previously described in the Bialowieza Primeval Forest in Poland (Kwiatkowski and Pedrotti 1994). Increase of the thickness of the O horizon in conifer/pioneer species plots since 1930 indicates ongoing podsolization processes due to coniferous litter accumulation. Compared to the conifer/pioneer-dominated group, stands in the Quercusdominated group were mixed with other broad-leaved tree species like A. platanoides and T. cordata. The thinner and well decomposed $\mathrm{O}$ horizon, sometimes minimally formed, with higher $\mathrm{pH}$, is typical of this canopy type (van Oijen et al. 2005). These soil features can be explained by additions to the soil of more easily decomposable and nutrient rich leaf litter (Hagen-Thorn et al. 2004), as also indicated by significantly higher $\mathrm{N}$ concentration in the Ah horizon. Concentrations of nitrogen, potassium, calcium and magnesium are higher in the canopy of deciduous forests with varying degrees than in canopy in coniferous forests (Bergmann 1988), which results in higher concentration of 
401 exchangeable cations and higher $\mathrm{pH}$ value in deciduous forest litter (Binkley 1995). The

402 lower $\mathrm{C}$ concentration in the $\mathrm{O}$ horizon might be explained by increased invertebrate 403 activity causing mixing of the horizons.

404 Q robur is a temperate climate tree species that commonly occurs on alkaline and 405 fertile soils characterized by relatively heavy soil texture and moisture conditions (Jones 406 1945). However, the species has a relatively wide ecological valence (Lawesson and 407 Oksanen 2002) and occurs in many forest types (European Environment Agency 2006; 408 Ikauniece et al. 2013). The Moricsala Nature Reserve is a case where Q. robur occurs on 409 less-fertile sandy soil conditions.

\subsection{Canopy composition in relation to past land-use and disturbance}

411 The long-term history of vegetation on Moricsala Island is not known. The reserve 412 was established on the island in 1912 to represent the best noble broad-leaved woodland 413 in the Baltic region (Kupffer 1931), but there is evidence that humans had direct impact 414 on its development. The evidence of charcoal in soil of most plots indicates past forest 415 fire. Considering the past agricultural land-use of the island at the beginning of the 1900s 416 and the traditional slash and burn traditions in the past, it seems likely that humans had 417 cleared the forest by fire at some unknown time. Isolated noble $Q$. robur trees with large 418 diameter and wide crowns were noted by Kupffer (1931) in forest habitat, typical of 419 overgrown wooded meadow. This, along with the relatively young age (90-110) of trees 420 in the Q. robur stands in 1930 (Grošinskis 1932), suggests that these Q. robur trees 421 regenerated in the early 1800 s after agricultural land-use or fire, as its establishment is 422 successful in non-intensively used pasture and hay fields (Vera 2000). We did not 423 determine age of Q. robur, but other published (Brūmelis et al. 2011) and unpublished 424 studies in the island give a maximum age of 240 years, with most canopy trees about 180- 
425200 years, which is in conformity with the earlier study. The noted occurrence of $P$.

426 tremula snags and logs in the Q. robur stands in 1930, and subsequent decreases in basal

427 area and/or occurrence of the pioneer tree species Betula sp. and P. tremula, also suggest

428 past regeneration of pioneer species in open areas and subsequent mortality with canopy

429 closure. The significantly higher density of Q. robur in the shrub layer of the

430 conifer/pioneer tree species group in 1930 also suggests that the past land-use created

431 suitable conditions for establishment and recruitment to the canopy layer.

432 Establishment of Q. robur in the understory was still occurring in 1930, but it was

433 lacking in the understory in 2011. Recruitment of Q. robur from the understory to the

434 canopy stage is unsuccessful under a deciduous canopy (Falinski 1986, 1988). However,

435 there is evidence that $Q$. robur can successfully establish under conifer canopies,

436 provided sufficiently lit conditions free from competitive vegetation (Götmark et al.

437 2005). There were few significant changes in total basal diameter of tree species in plots

438 during the 80 -year period. Basal area of $Q$. robur had increased, suggesting its continued

439 presence in the tree canopy. Long-term persistence of $Q$. robur in woodland can be

440 explained by its long life span, ecological plasticity in habitat and growth, and ability to

441 survive disturbances (Götmark and Kiffer 2014). However, T. cordata has been observed

442 to successfully recruit to the overstory in Q. robur on Moricsala Island (Brūmelis et al.

443 2011), as also was suggested by the large (non-significant) increase in mean basal area of

444 T. cordata. Data from five permanent plots established in 1936 in Pino-Quercetum and

445 Tilio-Carpinetum communities in the Bialowieza reserve indicated replacement of $Q$.

446 robur by P. abies, T. cordata, and Carpinus betulus (Falinski 1986).

447 One of the reasons for poor establishment of Quercus robur might be due to seed

448 predation by boar, which was rare in Latvia in the early 1900s. The population has much 
449 increased in Latvia, and groups of 5-6 boars, rarely up to over 30, regularly visit the

450 island for a few weeks in autumn to forage, presumably attracted by acorn crops (Vilnis

451 Skuja, personal communication). In the isolated area of the island, such densities are

452 extremely high and they can cause extensive damage such as uplifting of the soil

453 (personal observation). Currently, however, regulation of the boar population is not

454 permitted in the reserve. Individual roe deer occasionally also visit the island for short 455 periods, but damage to saplings is likely minimal.

456 Major storms in the early 1900s (Kupffer 1931) and in 1967 and 1969 (Abolina et

457 al., 1979) were documented to have selectively caused extensive mortality of $P$. abies on

458 Moricsala Island. The wide occurrence of pioneer tree species and low success of P. abies

459 in recruiting to the canopy can therefore partly be explained by wind disturbance. Its low

460 density in the shrub layer of the Quercus-dominated stands suggests that the conservation

461 value of these stands is nor threatened in the near future by recruitment to the canopy

462 layer. We noted that throughout the island P. tremula was being selectively cut by beaver,

463 an animal that was extinct in the early 1900s. Thus, in contrast with the Quercus-

464 dominated stands, disturbance will continue to be a major factor affecting tree and herb

465 species composition in the conifer/pioneer tree species group, and this might provide

466 opportunities for recruitment of Q. robur. The future changes in tree species composition

467 on Moricsala Island will be determined by competitive exclusion, tree longevity and

468 disturbance.

$469 \quad$ 4.3. Changes in vegetation in relation to soil and canopy factors

470 In 1930, the vegetation of the conifer/pioneer tree species stands differed from the

471 Q. robur stands in higher abundance of species with ecological characteristics

472 (therophyte, hemiphanerophyte, ruderal strategy, and wind dispersed) of open habitats. In 
4732011 , species of open habitats were still more abundant in this group, but species

474 characteristic of forest habitats, geophytes, plants with both geophyte and

475 heimicryptophyte life form, and a stress-tolerant strategy, which are features that are

476 characteristic of ancient forest species (Hermy et al. 1999), had increased in occurrence.

477 In the Q. robur stands, few significant differences in the period between studies

478 occurred in ecological characteristics of the vegetation, suggesting general stability of the

479 vegetation communities. Abundance of species typical of moist habitat increased, as

480 might be expected after less light exposure due to canopy closure. Chamaephytes, which

481 have sensitive buds located slightly above the soil, had higher occurrence in the $Q$. robur

482 stands, compared to the conifer/pioneer tree species group, in both years of study. These

483 species have been observed to increase in abundance after cessation of the previous

484 human impact (Roovers et al. 2005), which can explain their lower occurrence in the

485 disturbed stands. In 2011, species with seed dispersal by ants, which is at small distances,

486 had higher occurrence in the $Q$. robur stands, suggesting that greater time would be

487 needed for these species to colonize the disturbed stands. Dispersal by ants at short

488 distances is a plant trait described to be common of old deciduous woodland, as recovery

489 of typical woodland communities after agricultural land-use occurs after a long time due

490 to dispersal constraints (Ikauniece et al. 2013). The decrease of abundance of plants with

491 a competitive stress-tolerant strategy and autochorous seed dispersal in the Q. robur

492 stands is difficult to explain and might have occurred by chance. In line with the

493 differences in soil variables between the stand groups, Q. robur stands had greater

494 abundance of species with higher Ellenberg $\mathrm{pH}$ and $\mathrm{N}$ values. However, this difference

495 occurred only in 2012, which might suggest an effect of richer leaf litter on soil nutrient

496 regime favouring growth of competitive species, like Aegopodium podagraria, which was 
497 more common in the Q. robur stands in both years. Use of semi-permanent plots for study

498 of plant communities has shown that the abandonment of coppicing as a traditional form

499 of management has led to increased shading, causing shifts from more thermophilous

500 towards more nutrient demanding species (van Calster et al. 2008; Hédl et al. 2010). This

501 was also observed on Moricsala Island, with species of open habitats decreasing in the

502 conifer-pioneer tree species group, and nutrient-demanding species becoming more

503 frequent in the $Q$. robur stands.

504 Compositional differences between recent secondary forest and ancient forest can

505 persist for decades (Baeten et al. 2010). In our study, differences in vegetation between

506 the two tree groups were still evident after 80 years, which can be explained by persisting

507 soil and canopy factors. Nevertheless, the NMS ordination of vegetation data showed a

508 unidirectional shift in vegetation of seven of nine conifer/pioneer tree species stands, due

509 to replacement of open species like Fragaria vesca, Veronica chamaedrys and

510 Melampyrum nemorosum with typical forest species like Circaea lutetiana, Oxalis

511 acetosella and Galium odoratum. The decreased occurrence of species common to boreal

512 woodland, like Vaccinium sp, and Luzula pilosa might also be explained by increased

513 shading conditions. As distribution of species with different life histories is associated

514 with soil $\mathrm{pH}$, nitrogen mineralization, and amount of organic material in soil (van Oijen et

515 al. 2005), the typical nemoral flora under a broadleaved canopy may be altered by soil

516 and shading conditions that evolve after development of an P. abies understory (Ikauniece

517 et al. 2013). However, there was no evidence of significant recruitment of P. abies to

518 either of the two groups of stands, which would endanger the value of the reserve as a

519 reference area for the noble broad-leaved tree species stands. The two stands of the

520 disturbed conifer/pioneer tree species group that were misplaced in the NMS ordination 
521 of vegetation data were in 1930 dominated by $P$. tremula, which was replaced by $Q$.

522 robur in 2011, which can explain the similarity of vegetation in these plots with that in

523 other plots of the Quercus-dominated group. This suggests that successful recruitment of

524 Q. robur in the canopy of the disturbed stands might be possible, along with the

525 development of the typical plant communities.

526 Changes in the ecological characteristics of plant communities in the Q. robur stands

527 showed few changes over time. This suggests the strong role of the canopy and soil in

528 determining formation of the plant community composition from the pool of species that

529 can establish in the existing conditions. However, the NMS ordination showed that

530 trajectories of compositional change in the Q. robur stands were unpredictable, perhaps

531 due to a shifting mosaic of ground layer conditions created by tree mortality and and

532 perhaps by uplifting of the topsoil by boar. Vegetation composition of the disturbed

533 stands will continue to change, and differences in community composition with the $Q$.

534 robur stands can be expected to continue in the near future.

535 4.4. Management implications

536 Management of the Moricsala Nature Reserve since its establishment in 1912 has been by

537 strictly enforcing non-intervention. It has served as a reference area for natural

538 development of woodland after previous land-use for pasture and hay collection.

539 Regeneration of Q. robur on the island was likely promoted by past traditional human

540 practices. Although Q. robur is presently not regenerating in the understory, it will persist

541 in the canopy due to its longevity. There was no evidence of invasion of $P$. abies in the

542 shrub layer of the noble broad-leaved stands, which would endanger their conservation

543 value. In stands previously dominated by conifer and pioneer trees species, $Q$. robur was

544 the only tree species that showed significantly increased basal area, indicating its ability 
545 to outlive the other tree species. There was little change in composition of herbaceous

546 vegetation in Quercus-dominated stands, while the conifer/pioneer tree species dominated

547 stands had decreased occurrence of species characteristic of the past open forest habitats

548 affected by human land-use. Our study showed that there is no reason for changing the

549 non-intervention management regime on the island, with the exception of exerting some

550 control on boar populations in autumn to minimize seed predation and ground

551 disturbance.

552

553

554

555

556

557 


\section{Acknowledgements}

559 The study was financially supported by the ESF project 560 2013/0020/1DP/1.1.1.2.0./13/APIA/VIAA/066 „Interdisciplinary Team of Young 561 Scientists for Assessment and Restoration of Soil Quality and Usage Potential in Latvia”. 562 Permission to conduct the field work was given by the Latvian Nature Conservation 563 Agency. The help of many persons in conducting field work is greatly appreciated.

564 The comments of anonymous reviewers much helped to improve the manuscript. 


\section{References}

Abolina, A., Gemste, J., Laivina, S. \& Laivins, M. 1979. Pochvy I Rastitelnost

Prirodnogo Rezervata Moricsala [Soils and vegetation of the Moricsala Reserve].

Riga: Zinatne. (In Russian.)

Baeten, L., Hermy, M., Van Daele, S., and Verheyen, K. 2010. Unexpected

understorey development after 30 years in ancient and post-agricultural forests. J.

Ecol. 98: 1447-1553. doi: 10.1111/j.1365-2745.2010.01711.x

Benavides, J., and Koster, E. 2006. Identifying surviving landmarks on historical maps. e-Perimetron. 1(3): 194-208. Available from http:// http://www.eperimetron.org/Vol_1_3/Benavides_Koster.pdf [accessed 23 november 2014].

Berg, B. 2000. Litter decomposition and organic matter turnover in northern forest soils. For. Ecol. Manage. 133(1-2): 13-22. doi:10.1016/S0378-1127(99)00294-7.

Bergmann, W. 1988. Ernährunsstörungen bei Kulturpflanzen. Entstehung, visuelle und analytische diagnoze, Bergmann W. (Ed.), 2e édition, Gustav Fisher Verlag, Stuttgart.

Binkley, D. 1995. The influence of tree species on forest soils: processes and patterns. In Proceeding of the Trees and Soil Workshop, Lincoln University 28 February-2 March 1994. Edited by D.J. Mead, and I.S. Cornforth. Lincoln University Press, Canterbury, pp. 1-33.

Bobiec, A. 2012. Białlowieża Primeval Forest as a remnant of culturally modified ancient forest. Eur. J. For. Res. 131: 1269-1285. 
Bonifacio, E., Caimi, A., Falsone, G., Trofimov, S.Ya., Zanini, E., Godbold, D.L., 2008. Soil properties under Norway spruce differ in spruce dominated and mixed broadleaf forests of the Southern taiga. Plant Soil 308, 149-159.

Bradshaw, R., and Hannon, G. 2004. The Holocene structure of north-west European forest induced from palaeoecological data. In Forest Biodiversity: Lessons from History for Conservation. Edited by O. Honnay, K. Verheyen, B. Bossuyt and M. Hermy,. CAB International, Oxford. pp. 11-25.

Brūmelis, G., Dauškane, I., Ikauniece, S., Javoiša, B., Kalviškis, K., Madžule, L., Matisons, R., Strazdina, L., Tabors, G., and Vimba, E. 2011. Dynamics of natural hemiboreal woodland in the Moricsala Reserve, Latvia: the studies of K. R. Kupffer revisited. Scan. J. For. Res. 26(S10): 54-64. doi: 10.1080/02827581.2011.517944.

Cools, N., and de Vos, B. 2010. Sampling and analysis of soil. Manual part X. In Manual on methods and criteria for harmonized sampling, assessment, monitoring and analysis of the effects of air pollution on forests, UNECE, ICP Forests, Hamburg. p. 208. Available from http://www.icp-forests.org/pdf/FINAL_soil.pdf [accessed 23 November 2014].

El-Hussainy, M.S., Baraka, M.A., and El-Hallaq, M.A. 2011. A methodology for image matching of historical maps. e-Perimetron 6(2): 77-5. http://www.eperimetron.org/Vol_6_2/Hussainy_et_al.pdf [accessed 23 November 2014].

Ellenberg, H., Weber, H.E., Dull, R., Wirth, V., Werner, W., and Paulisen, D. 1991. Zeigerwerte von Pflanzen in Mitteleuropa [Indicator values of plants in Central Europe]. Scripta Geobotanics 18. Verlag Erich Goltze KG, Göttingen, pp. 1-248. 
European Environment Agency. 2006. European forest types. EEA Technical report No. 9/2006.

FAO. 2006. Guidelines for Soil Description. Fourth edition. FAO, Rome.

Falinski, J.B. 1986. Treee stand dynamics in Pino-Quercetum and Tilio-Carpinetum communities. In Vegetation Dynamics in Temperate Lowland Primeval Forests. Dr. Junk Publishers, Dordrecht. pp. 217-228.

Falinski, J.B. 1988. Succession, regeneration and fluctuation in the Bialowieza Forest (NE Poland).Vegetatio. 77: 115-128. doi: 10.1007/978-94-009-2275-4_13.

Fitter, A.H., Peat, H.J., 1994. The Ecological Flora Database. J. Ecol. 82: 415-425.

Götmark, F., Fridman, J., Kempe, G., and Norden, B. 2005. Broadleaved tree species in conifer dominated forestry: regeneration and limitation of saplings in southern Sweden. For. Ecol. Manage. 214(1-3): 142-157. doi:10.1016/j.foreco.2005.04.001.

Götmark, F.,Kiffer, C. 2014. Regeneration of oaks (Quercus robur/Q. petraea) and three other tree species during long-term succession after catastrophic disturbance (windthrow). Plant Ecol. 215: 1067-1080.

Grošinskis, J. V. 1932. Moricsalas meža tipi. Diplomdarbs. [Forest types on Moricsala Island, Dissertation]. Faculty of Agriculture, University of Latvia, Rīga.

Hagen-Thorn, A., Callesen, I., Armolaitis, K., and Nihlgard, B. 2004. The impact of six European tree species on the chemistry of mineral topsoil in forest plantations on former agricultural land. For. Ecol. Manage. 195(3): 373-384.

doi:10.1016/j.foreco.2004.02.036. 
Hédl, R., Kopecký, M., and Komárek J. 2010. Half a century of succession in a temperate oakwood: from species-rich community to mesic forest. Divers. Distrib. 16(2): 267-276. doi: 10.1111/j.1472-4642.2010.00637.x.

Hermy, M., and Verheyen, K. 2007. Legacies of the past in the present-day forest biodiversity: a review of past land-use effect on forest plant species composition and diversity. Ecol. Res. 22: 361-371. doi: 10.1007/s11284-007-0354-3.

Hermy, M., Honnay, O., Firbank, L., Grasof-Bokdam, C., Lawesson, J.E. 1999. An ecological comparison between ancient and other forest plant species in Europe and the implications for forest conservation. Biol. Conserv. 91(1): 9-22. doi:10.1016/S0006-3207(99)00045-2

Hothorn, T., Hornik, K., van de Wiel, M.A., Zeileis, A. 2008. Implementing a class of permutation tests: the coin package. J. Stat. Softw. 28(8): 1-23. doi:

10.18637/jss.v028.i08

Ikauniece, S., Brūmelis, G., Kasparinskis, R., Nikodemus, O., Straupe, I., and Zariņš J. 2013. Effect of soil and canopy factors on vegetation of Quercus robur woodland in the boreo-nemoral zone: A plant-trait based approach. For. Ecol. Manage. 295: 43-50. doi:10.1016/j.foreco.2013.01.019.

ISO 10694. 1995. Soil Quality - Determination of organic and total carbon after dry combustion (elementary analysis). International Organization for Standardization. Geneva, Switzerland. 7 p. Available from http://www.iso.ch [accessed 23 November 2014].

ISO 13878. 1998. Soil Quality - Determination of total nitrogen content by dry combustion ("elemental analysis"). International Organization for Standardization. 
Geneva, Switzerland. 5 p. Available from http:/www.iso.ch [accessed 23

November 2014].

IUSS Working Group WRB. 2014. World Reference Base for soil resources 2014. International soil classification system for naming soils and creating legends for soil maps. World Soil Resources Report No. 106. FAO, Rome. Available from http://www.fao.org/3/a-i3794e.pdf [accessed 23 November 2014].

Jenny, H. 1994. Factors of Soil Formation. A System of Quantitative Pedology. Dover Publications Inc, New York, NY. Available from http://www.soilandhealth.org/01aglibrary/010159.Jenny.pdf [accessed 23 November 2014].

Jones, E.W. 1945. The structure and reproduction of the virgin forest of the north temperate zone. New Phytologist. 44(2): 130-148. Available from http://www.jstor.org/stable/2428813 [accessed 23 November 2014].

Kirby, K.J., Smart, S.M., Black, H.I.J., Bunce, R.G.H., Corney, P.M., and Smithers, R.J. 2005. Long term ecological change in British woodland (1971-2001). A resurvey and analysis of change based on 103 sites in the Nature Conservancy 'Bunce 1971' woodland survey. English Nature Research Report number 653. English Nature, Peterborough.

Kühn, I., Durka, W., Klotz, S., 2004. BiolFlor - a new plant-trait database as a tool for plant invasion ecology. Divers. Distrib. 10: 363-365. doi: 10.1111/j.13669516.2004.00106.x. (supplementary material available from http://www.blackwellpublishing.com/products/journals/suppmat/DDI/DDI106/DD I106sm.htm. 
Kupffer, K.R. 1931. Die Naturschonstätte Moritzholm. Arbeiten des NaturforscherVereins zu Riga Neue Folge, 19: 1-138.

Kwiatkowski, W., and Pedrotti, F. 1994. Determinism and the origin of vegetation differentiation. Geo-ecological forest landscapes. Phytocoenosis 6 (N.S.).

Supplementum Cartographiae Geobotanicae 4. Warszawa - Biolowieža, pp.119_ 125.

Lawesson, J. E., and Oksanen, J. 2002. Niche charasteristics of Danish woody species as derived from coenoclines. J. Veg. Sci. 13(2): 279-290. doi: 10.1111/j.16541103.2002.tb02048.x.

Lundström, U.S., Van Breemen, N., and Bain, D. 2000. The podzolization process. A review. Geoderma. 94(2/4): 91-107. doi:10.106/S0016-7061(99)00036-1.

McCune, B., and Grace, J.B. 2002. Analysis of Ecological Communities. MjM Software, Gleneden Beach, Oregon, US.

Palo, A., Ivask, M., and Liira, J. 2013. Biodiversity composition reflects the history of ancient semi-natural woodland and forest habitats - Compilation of an indicator complex for restoration practice. Ecol. Indic. 34: 336-344. doi:

10.1016/j.ecolind.2013.05.020.

Peterken, G.F. 1996. Virgin forest remnants in Europe. In Natural Woodland. Ecology and Conservation in Northern Temperate Regions. Cambridge University Press, New York. pp. 37-45.

R Core Team (2015) R: a language and environment for statistical computing. R Foundation for Statistical Computing, Vienna, Austria. URL http://www.Rproject.org/. 
Roovers, P., Bossuyt, B., Gulink, H., and Hermy, M.J. 2005. Vegetation recovery on closed paths in temperate deciduous forests. J. Environ. Manage. 74(3): 273-81. doi: 10.1016/j.jenvman.2004.10.003

Van Calster, H., Baeten, L., Verheyen, K., De Keersmaeker, L., Dekeyser, S., Rogister, J.E., and Hermy, M. 2008. Diverging effects of different overstorey conversion scenarios on the understorey vegetation in a former coppice-withstandards forest. For. Ecol. Manage. 256(4): 519-528.

doi: 10.1016/j.foreco.2008.04.042.

Van Calster, H., Baeten, L., De Schrijver, A., De Keersmaeker, L., Rogister, J.E., Verheyen, K., Hermy, M. 2007. Management driven changes (1967 - 2005) in soil acidity and the understory plant community following conversion of a coppicewith-standards forest. For. Ecol. Manage. 241, 258-271

Van Oijen, D., Feijen, M., Hommel, P., den Ouden, J., de Waal, R. 2005. Effects of tree species composition on within-forest distribution of understorey species. Appl. Veg. Sci. 8(2): 155-166. doi: 10.1111/j.1654-109x.2005.tb006412.x.

Van Reeuwijk, L.P. 1995. Procedures for soil analysis. 5th ed. ISRIC Technical Paper 9. Wageningen, The Netherlands.

Vera, F.W. 2000. Grazing Ecology and Forest History. CABI Publishing, Wallingford, Oxon, UK.

Vesterdal, L. 1999. Influence of soil type on mass loss and nutrient release from decomposing foliage litter of beech and Norway spruce. Can. J. For. Res. 29(1): 95-105. doi: 10.1139/x98-182. 
Vesterdal, L., and Raulund-Rasmussen K. 1998. Forest floor chemistry under seven tree species along a soil fertility gradient. Can. J. For. Res. 28(11): 1636-1647. doi: $10.1139 / \mathrm{x} 09-022$.

Vesterdal, L., Schmidt, I.K., Callesen, I.,Nilsson, L.O., and Gundersen, P. 2008.

Carbon and nitrogen in forest floor and mineral soil under six common European tree species. For. Ecol. Manage. 255(1): 35-48. doi:10.1016/j.foreco.2007.08.015. 
Table 1. Characteristics of forest plots on Moricsala Island (Grošinskis 1932).

Evidence of charcoal (in 2011) indicating past fire shown by a "+". Maximum age of sampled overstory trees in 1928-1930 is given.

\begin{tabular}{|c|c|c|c|c|}
\hline $\begin{array}{l}\text { Plot } \\
\text { no. }\end{array}$ & $\begin{array}{l}\text { Dominant canopy } \\
\text { species }\end{array}$ & $\begin{array}{l}\text { Past } \\
\text { fire }\end{array}$ & Age & Comments (Grošinskis 1932) \\
\hline \multicolumn{5}{|c|}{ Quercus robur stands } \\
\hline 2 & $\begin{array}{l}\text { Q. robur, } T \text {. cordata, } \\
\text { A. platanoides }\end{array}$ & + & 90 & $\begin{array}{l}\text { several old } P \text {. tremula snags and logs; } \\
P . \text { tremula being replaced by lime and } \\
\text { maple in the subcanopy }\end{array}$ \\
\hline 3 & $\begin{array}{l}Q . \text { robur, } T \text {. cordata, } \\
\text { A. platanoides }\end{array}$ & + & 110 & $\begin{array}{l}\text { large decomposed stumps (cut) - two } P \text {. } \\
\text { tremula stumps and two oak; very } \\
\text { decomposed logs and branches }\end{array}$ \\
\hline 4 & $\begin{array}{l}\text { Q. robur, } T \text {. cordata, } \\
\text { A. platanoides }\end{array}$ & + & 90 & $\begin{array}{l}7 \text { wind-thrown and partially } \\
\text { decomposed tall aspen }\end{array}$ \\
\hline 5 & $\begin{array}{l}Q . \text { robur, } P \text {. tremula, } \\
P . \text { abies }\end{array}$ & + & 100 & many wind-thrown, decomposed aspen \\
\hline 7 & $\begin{array}{l}\text { Q. robur, } P \text {. tremula, } \\
\text { A. platanoides, }\end{array}$ & + & 100 & a few aspen and Sorbus logs \\
\hline 14 & $\begin{array}{l}\text { Q. robur, } \\
\text { A. platanoides }\end{array}$ & + & 110 & $\begin{array}{l}\text { no human activity, no stumps or dead } \\
\text { wood (very dense shrub understorey) }\end{array}$ \\
\hline 15 & $\begin{array}{l}\text { Q. robur, } \\
\text { A. platanoides }\end{array}$ & + & 110 & $\begin{array}{l}\text { no human activity, fallen large tree } \\
\text { branches }\end{array}$ \\
\hline 16 & Q. robur & & 110 & $\begin{array}{l}\text { no human activity, fallen large tree } \\
\text { branches and trees }\end{array}$ \\
\hline & & & & \\
\hline \multicolumn{5}{|c|}{$\begin{array}{l}\text { Conifer/pioneer tree species } \\
\text { stands }\end{array}$} \\
\hline 11 & $\begin{array}{l}P . \text { sylvestris, } Q . \\
\text { robur, } \\
P . \text { tremula }\end{array}$ & & 120 & $\begin{array}{l}\text { previous wooded pasture, } 3 P \text {. } \\
\text { sylvestris stumps and one pine log, on } \\
\text { border with meadow }\end{array}$ \\
\hline 22 & $\begin{array}{l}\text { P. sylvestris, } Q . \text { robur } \\
\text { Betula spp }\end{array}$ & & 100 & $\begin{array}{l}\text { previous wooded pasture, some pine } \\
\text { stumps; very open } P \text {. sylvestris stand; } \\
\text { previously without trees }\end{array}$ \\
\hline 9 & $\begin{array}{l}\text { P. sylvestris, Betula } \\
\text { spp. }\end{array}$ & + & 150 & $\begin{array}{l}1 \text { oak and } 5 P \text {. tremula cut stumps; } 5 P \text {. } \\
\text { tremula logs; spruce canopy forming }\end{array}$ \\
\hline 20 & $\begin{array}{l}\text { P. sylvestris, Betula } \\
\text { spp. , Q. robur }\end{array}$ & + & 140 & many cut pine stumps; fire about 1900 . \\
\hline 19 & Betula spp. & + & 30 & $\begin{array}{l}\text { decomposed } P . \text { abies, } P . \text { sylvestris and } \\
Q . \text { robur stumps; fire about } 1900 .\end{array}$ \\
\hline 6 & P. tremula, Q. robur & + & 100 & $\begin{array}{l}5 \text { old } P . \text { tremula stumps }(\operatorname{logs} \\
\text { removed); two aspen logs }\end{array}$ \\
\hline 21 & $\begin{array}{l}\text { P. tremula, } Q \text {. robur, } \\
\text { A. platanoides }\end{array}$ & & 105 & $\begin{array}{l}\text { no human activity, no stumps or dead } \\
\text { wood }\end{array}$ \\
\hline 8 & $\begin{array}{l}\text { P. abies, Q. robur, } \\
P . \text { tremula }\end{array}$ & + & 125 & $\begin{array}{l}\text { in } 1900 \text { tall } P \text {. abies that later suffered } \\
\text { mortality from wind and bark beetle. }\end{array}$ \\
\hline 18 & $\begin{array}{l}P . \text { abies, } P \text {. sylvestris, } \\
\text { Q. robur }\end{array}$ & + & 110 & $P$. abies replacing $Q$. robur \\
\hline
\end{tabular}


Table 2. Mean basal area $\left(\mathrm{m}^{2} \mathrm{ha}^{-1}\right)$ of living trees in plots on Moricsala Island. Significant differences between conifer/pioneer tree species and Quercus-dominated plots (permutation test) are indicated by different letters (A and B for basal area and X and $\mathrm{Y}$ for occurrence in plots). Significant differences between years are shown by bold font (paired permutation test) and for occurrence in plots by italics (test for equality of proportions).

\begin{tabular}{|c|c|c|c|c|}
\hline & & \multicolumn{2}{|c|}{ Mean basal area $\left(\mathrm{m}^{2} \mathrm{ha}^{-1}\right)$} & \\
\hline & $\begin{array}{l}\text { conifer/pioneer } \\
\text {-dominated }\end{array}$ & $\begin{array}{l}\text { Quercus- } \\
\text { dominated }\end{array}$ & $\begin{array}{l}\text { conifer/pioneer } \\
\text { - dominated }\end{array}$ & $\begin{array}{l}\text { Quercus- } \\
\text { dominated }\end{array}$ \\
\hline Quercus & $5.2^{\mathrm{A}}$ & $12.5^{\mathrm{B}}$ & 9.8 & 15.7 \\
\hline Tilia & $0.7^{\mathrm{A}}$ & $5.3^{\mathrm{B}}$ & 4.7 & 12.1 \\
\hline Acer & $0.9^{\mathrm{A}}$ & $7.0^{B}$ & 2.8 & 2.0 \\
\hline Picea & 5.0 & 0.7 & 7.3 & 1.3 \\
\hline Pinus & $10.9^{\mathrm{A}}$ & $0.8^{\mathrm{B}}$ & $9.8^{\mathrm{A}}$ & $0.3^{\mathrm{B}}$ \\
\hline Populus & $5.4^{\mathrm{X}}$ & $1.2^{\mathrm{Y}}$ & 3.9 & 0.5 \\
\hline Betula & $3.8^{\mathrm{A}}$ & $0.6^{\mathrm{B}}$ & 3.1 & 0.0 \\
\hline
\end{tabular}


Table 3. Densities of tree sapling and shrub species in plots on Moricsala Island.

Significant differences between conifer/pioneer tree species and Quercus-dominated plots (permutation test) are indicated by different letters (A and B for mean density and $\mathrm{X}$ and $Y$ for occurrence in plots). Significant differences between years for sapling densities are shown by bold font (paired permutation test) and for occurrence in plots by italics (test for equality of proportions).

\begin{tabular}{|c|c|c|c|c|}
\hline \multicolumn{3}{|c|}{ Mean number stems ha $^{-1}$} & \multirow{2}{*}{\multicolumn{2}{|c|}{2011}} \\
\hline & 1930 & & & \\
\hline $\begin{array}{l}\text { Saplings/shrub } \\
\text { species }\end{array}$ & $\begin{array}{l}\text { conifer/pioneer } \\
\text { dominated }\end{array}$ & $\begin{array}{l}\text { Quercus- } \\
\text { dominated }\end{array}$ & $\begin{array}{l}\text { conifer/pioneer } \\
\text { dominated }\end{array}$ & $\begin{array}{l}\text { Quercus- } \\
\text { dominated }\end{array}$ \\
\hline Quercus & $272^{\mathrm{A}}$ & $31^{\mathrm{B}}$ & 0 & 0 \\
\hline Picea & $2423^{X}$ & $188^{\mathrm{Y}}$ & 243 & 55 \\
\hline Tilia & 623 & 1272 & 602 & 1196 \\
\hline Acer & 1447 & 688 & 396 & 203 \\
\hline Pinus & 73 & 0 & 0 & 0 \\
\hline Populus & 203 & 65 & 521 & 0 \\
\hline Betula & 178 & 0 & 14 & 8 \\
\hline Padus & 216 & 1908 & 757 & 4430 \\
\hline Sorbus & 1505 & 375 & 209 & 39 \\
\hline Corylus & 1653 & 3062 & 1201 & 1954 \\
\hline Frangula & 75 & 0 & 14 & 0 \\
\hline Juniper & 6 & 0 & 0 & 0 \\
\hline Salix & 32 & 0 & 14 & 0 \\
\hline Crataegus & 17 & 0 & 0 & 0 \\
\hline Malus & 6 & 6 & 0 & 0 \\
\hline
\end{tabular}


Table 4. Characterization of soil properties in Moricsala Island. Mean and range of values in soil pits studied in 2011 are given. Significant differences between conifer/pioneer tree species and Quercus-dominated plots (permutation test) are indicated by bold font. * with Bonferoni correction.

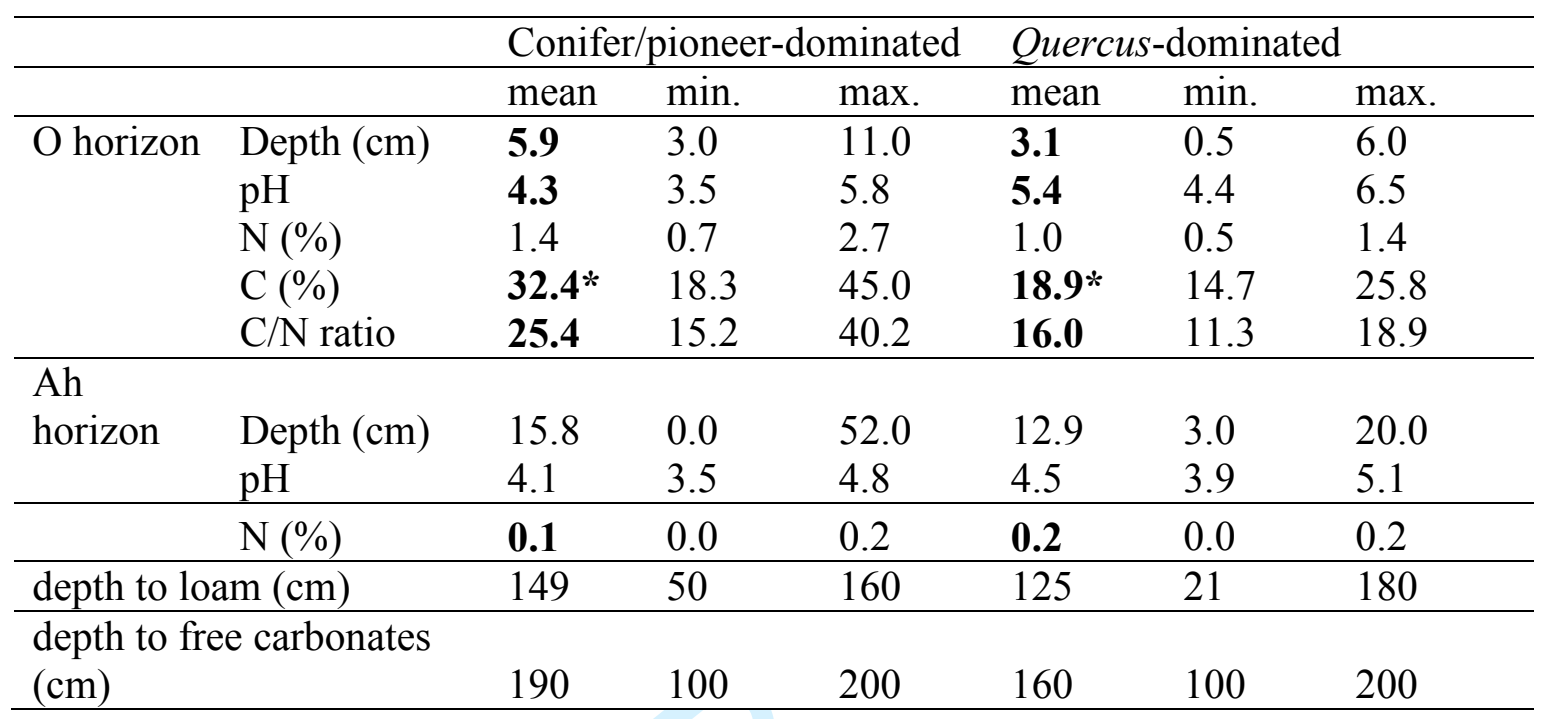


Table 5. Significant differences (permutation test) in relative frequency of ecological characteristics and weighted mean Ellenberg values ( $\mathrm{pH}$ and $\mathrm{N}$ ) of conifer/pioneer tree species and Quercus-dominated plots on Moricsala Island. Characteristics are given for the plot group with higher value. * with Bonferoni correction.

\begin{tabular}{|c|c|c|c|c|c|}
\hline 1930 & & & 2011 & & \\
\hline $\begin{array}{l}\text { Conifer/pioneer } \\
\text {-dominated }\end{array}$ & $\begin{array}{l}\text { Quercus- } \\
\text { dominated }\end{array}$ & $\mathrm{p}$ value & $\begin{array}{l}\text { Conifer/pioneer } \\
\text {-dominated }\end{array}$ & $\begin{array}{l}\text { Quercus- } \\
\text { dominated }\end{array}$ & $\begin{array}{l}\mathrm{p} \\
\text { value }\end{array}$ \\
\hline \multicolumn{6}{|l|}{ hemiphanerophyt } \\
\hline e & & $0.005^{*}$ & hemiphaneropyte & & 0.051 \\
\hline therophyte & & 0.016 & open & & $0.006^{*}$ \\
\hline anemochorous & & 0.023 & $\mathrm{~S}$ & & 0.026 \\
\hline $\mathrm{CR}$ & & 0.034 & forest & & 0.036 \\
\hline \multirow[t]{5}{*}{ open habitats } & & 0.054 & & $\mathrm{pH}$ & $0.009 *$ \\
\hline & autochorous & 0.031 & & \multirow{2}{*}{$\begin{array}{l}\text { chamaephyte } \\
\text { Forest and } \\
\text { grassland }\end{array}$} & 0.012 \\
\hline & \multirow{3}{*}{$\begin{array}{l}\text { CSR } \\
\text { chamaephyt } \\
\text { e }\end{array}$} & 0.033 & & & 0.019 \\
\hline & & 0.010 & & $\mathrm{~N}$ & 0.030 \\
\hline & & & & myrmecochorous & 0.030 \\
\hline
\end{tabular}


Table 6. Significant differences (paired permutation test) between 1930 and 2011 in relative frequency of ecological characteristics of conifer/pioneer tree species and Quercus-dominated plots on Moricsala Island.

\begin{tabular}{llll}
\hline & variable & $\begin{array}{l}\text { increase/ } \\
\text { decrease }\end{array}$ & $\mathrm{p}$ \\
\hline Conifer/pioneer & & & \\
-dominated & $\mathrm{S}$ & + & 0.014 \\
& zoochorous & + & 0.017 \\
& forest-grassland & - & 0.017 \\
& therophyte & - & 0.019 \\
& hemiphanerophyte & - & 0.019 \\
& geophyte & + & 0.038 \\
& CR & - & 0.040 \\
& moist habitats & + & 0.040 \\
& geophyte and & & \\
\hline huercus- & hemicryptophyte & + & 0.047 \\
dominated & moist habitats & + & 0.015 \\
& CS & - & 0.028 \\
& autochorous & - & 0.046 \\
\hline
\end{tabular}


Table 7. Significant differences (permutation test) in relative frequency of plants species of conifer/pioneer tree and Quercus-dominated plots on Moricsala Island. Placement of species in the conifer/pioneer-dominated versus Quercus-dominated columns indicates the plot group in which it had higher relative frequency. Species shown in bold also showed significant differences (test for equality of proportions) in occurrence in plots.

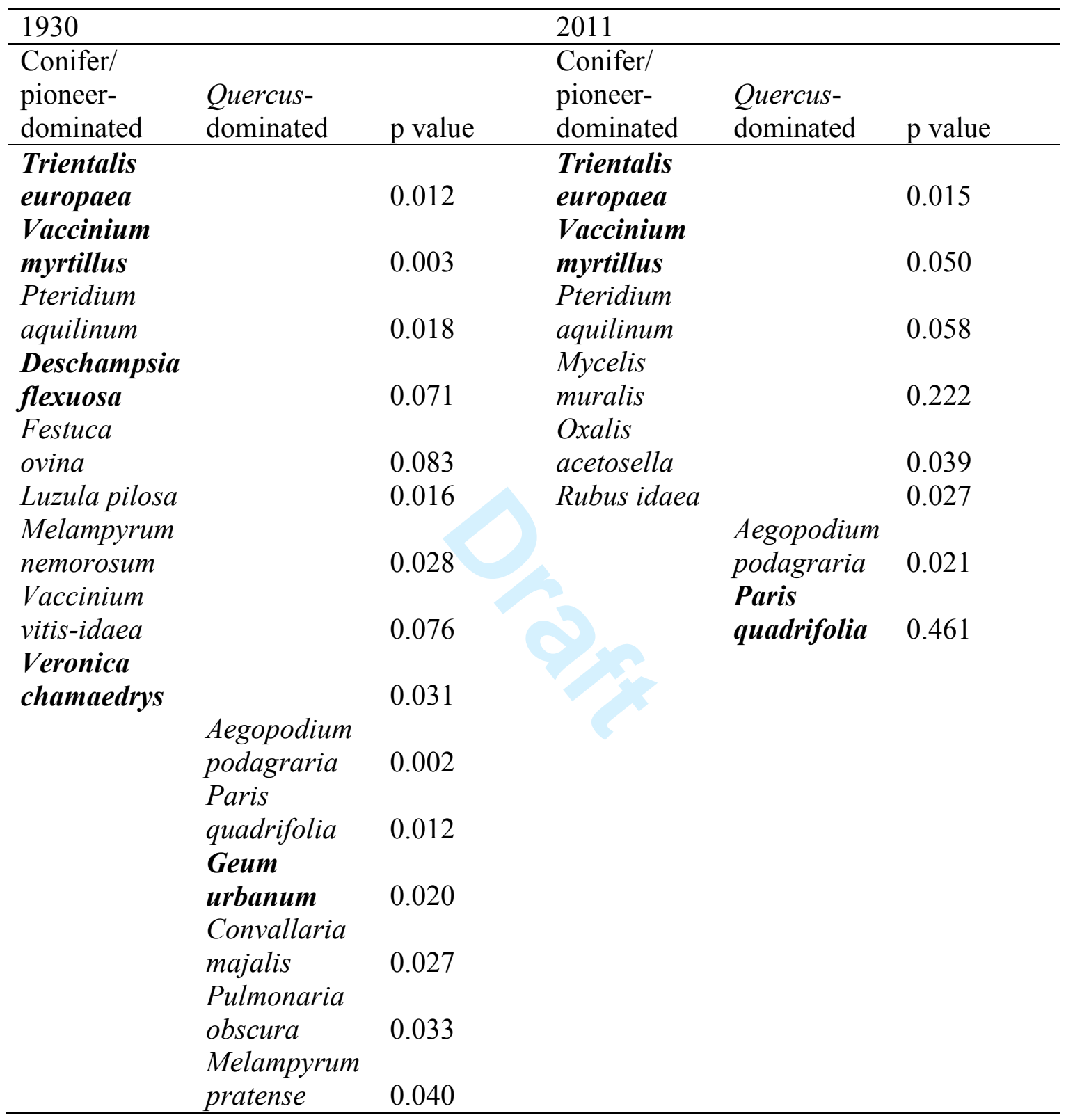


Table 8. Significant differences between 1930 and 2011 in relative frequency (paired permutation test) and overall occurrence of plant species (test for equality of proportions) in conifer/pioneer tree species and Quercus-dominated plots on Moricsala Island.

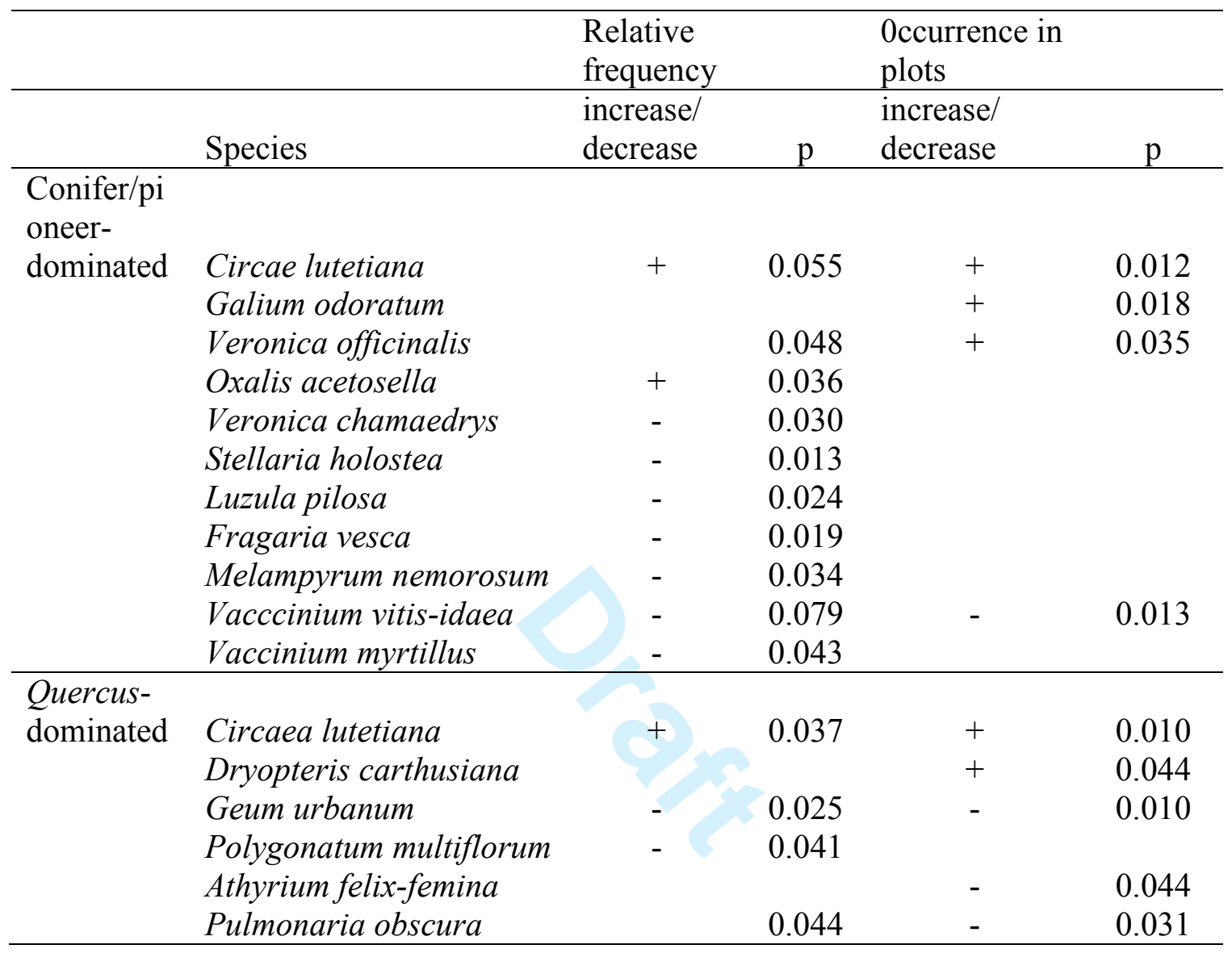




\section{Figures}

Fig. 1. Location of study area within (a) Europe and (b) Latvia is shown. (c) Location of 20 sample plots on Moricsala Island is shown, using WGS 84 coordinates.

Fig. 2. Cluster analysis (Ward's method with correlation distance measure) of forest plots. Plot numbers are given as in Table 1. Ovals denote conifer/pioneerspecies-dominated plots; square denotes Quercus-dominated group plots

Fig. 3. NMS ordination of vegetation matrix. A. Vectors indicate direction of change in vegetation composition in plots on Moricsala Island between the years of study (1930 and 2011). B. Open circles — conifer/pioneer-dominated group plots; black circles — Quercus-dominated group plots; abbreviations; Ellenberg values for $\mathrm{pH}$ and $\mathrm{N}$; life forms chamaephytes (cham), therophytes (ther), geophyte and hemiphanerophyte (geo/hemi), and hemiphanerophyte (hemiphan); habitat types open and forest/grassland (for/grass); myrmechochorous (Myrm) seed dispersal; and depth of the $\mathrm{O}$ horizon (O_hor). 


\section{Supplementary material. Description of methods used for determining coordinates of plots from historical maps.}

Historical map drafts and field manuscripts associated with the 1932 work were obtained from the family archives of J.V. Grošinskis (J.W.Grods). These 1932 paper maps were completed to 1:8400 scale with a common reference grid in metres with attached scale bars; these were considered to be drafts of the final map, which has been lost. The key 1932 map of focus, labelled "Moricsalas mežaudžu plāns" (Forest type map of Moricsala), not only delineated ecological polygons, but contained other map entities of plots, soil pits, soil borings (some of which were associated with vegetation plots), earlier cadastral survey lines and several annotated features and notes. This mapping was scanned at a 1:1 resolution set at 300 dpi into Geographic Information System ArcGIS 10.0 with Spatial Analyst 10.0 as a raster image where map entities were digitized. Two additional 1932 maps played a role in rectification of the "Moricsalas mežaudžu plāns" into the 2011 digital base. A base grid map was an earlier draft that illustrated also transects in a north to south azimuth not present on the final draft, along with a base gridded map. In the dissertation (Grošinskis 1932) it is noted that these maps were obtained from R. Meyers who surveyed the island in the period 1912-1915, and that they were used as the basis for construction of other maps; we presumed that the base grid map was a copy of this or the original. Transects and grid lines were determined to be every 100 meters, and the majority of 134 soil borings were aligned on these. According to descriptions in Kupffers (1931) and Grošinskis (1932), mapping of the edges of ecological polygons (including forest stands) stands, established vegetation plots, and soil pits and borings had been made by measuring distances and angles from transects denoted on Meyer's map, and were marked in the field and located on the Grozinskis map. These survey markers were 
not located in the present study and thus there were no exact reference points existing today that could be used for rectification. For georeferencing, an east-west meridian across the island anchored at the island's north-west point was established on the "Moricsalas mežaudžu plāns" map. As the key maps had referenced scales, using the north-west point, the historical map was used to measure the distance from the established meridian point to the first North-South transect line. This transect line was then imposed onto the meridian overlaid onto the recent imagery georeferenced to the LKS92 coordinate system, also a metric based coordinate system. The soil borings and distinguishable ecological features (43 control points) on the present day Moricsala ortho-image were then used to rectify the historical mapping using many iterations to optimize correspondence between the two maps based on a normalized cross correlation matrix, similar to processes outlined by Benavides and Koster (2006) and El-Hussainy et al (2011). Truthing was conducted by measuring the scale present on the transformed historical map and ensuring that transect lines ran North to South. The Pearson's correlation coefficient between matrices of inter-distances of control points on the historical and new image was 0.999 ( $\mathrm{p}<0.001$, Mantel test), which confirmed validity of the used method. 